\title{
AMENDMENTS
}

\section{Author Correction: Systematic comparison of single-cell and single-nucleus RNA-sequencing methods}

\author{
Jiarui Ding, Xian Adiconis, Sean K. Simmons, Monika S. Kowalczyk, Cynthia C. Hession, Nemanja D. Marjanovic, \\ Travis K. Hughes, Marc H. Wadsworth, Tyler Burks, Lan T. Nguyen, John Y. H. Kwon, Boaz Barak, William Ge (D), \\ Amanda J. Kedaigle (D), Shaina Carroll, Shuqiang Li, Nir Hacohen, Orit Rozenblatt-Rosen, Alex K. Shalek (D), \\ Alexandra-Chloé Villani, Aviv Regev (1) and Joshua Z. Levin (1)
}

Correction to: Nature Biotechnology https://doi.org/10.1038/s41587-020-0465-8, published online 6 April 2020.

In the version of this article initially published online, the Data Availability section listed the Single Cell Portal (https://portals.broadinstitute. org/single_cell). It has been revised to give Single Cell Portal accession numbers SCP424, SCP425 and SCP426. The change has been made in the print, PDF and HTML versions of the article.

Published online: 27 April 2020

https://doi.org/10.1038/s41587-020-0534-z

( $)$ The Author(s), under exclusive licence to Springer Nature America, Inc. 2020

\section{Author Correction: High-throughput single-cell activity-based screening and sequencing of antibodies using droplet microfluidics}

Annabelle Gérard (D), Adam Woolfe, Guillaume Mottet, Marcel Reichen, Carlos Castrillon (D), Vera Menrath, Sami Ellouze, Adeline Poitou, Raphaël Doineau (D), Luis Briseno-Roa, Pablo Canales-Herrerias (D), Pascaline Mary, Gregory Rose, Charina Ortega (D), Matthieu Delincé (D), Sosthene Essono, Bin Jia, Bruno lannascoli, Odile Richard-Le Goff, Roshan Kumar, Samantha N. Stewart, Yannick Pousse, Bingqing Shen, Kevin Grosselin, Baptiste Saudemont, Antoine Sautel-Caillé (D, Alexei Godina, Scott McNamara, Klaus Eyer (D), Gaël A. Millot DD, Jean Baudry (D), Patrick England, Clément Nizak (D), Allan Jensen, Andrew D. Griffiths (D), Pierre Bruhns (D) and Colin Brenan (D)

Correction to: Nature Biotechnology https://doi.org/10.1038/s41587-020-0466-7, published online 30 March 2020.

In the version of this article initially published online, the affiliation for Bin Jia was given as Abbvie Bioresearch Center, Worcester, MA, USA. This has been changed to reflect its status as a present address; the correct primary affiliation is Pfizer, Cambridge, MA, USA. The error has been corrected in the print, PDF and HTML versions of the article.

Published online: 22 May 2020

https://doi.org/10.1038/s41587-020-0563-7

(c) The Author(s), under exclusive licence to Springer Nature America, Inc. 2020 